\title{
Akut Serebrovasküler Olaylı Hastalarda Serum S100B Protein Düzeylerinin Lezyonun Tipi, Büyüklüğü ve Lokalizasyonu ile İlişkisi
}

\section{The Relationship between Serum S100B Protein Levels and Lesion Type, Size and Location in Patients with Acute Cerebrovascular Stroke}

\author{
Murat ALPUA ${ }^{1}$, Fatih BAKIR ${ }^{2}$, Neşe ÖZTEKİN ${ }^{3}$, Fikri AK ${ }^{3}$

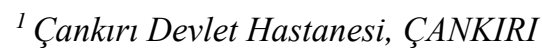 \\ ${ }^{2}$ Ankara Numune Eğitim ve Araştırma Hastanesi Biyokimya Kliniği, ANKARA \\ ${ }^{3}$ Ankara Numune Eğitim ve Araştırma Hastanesi Nöroloji Kliniği, ANKARA
}

\begin{abstract}
ÖZET
$\mathrm{Bu}$ çalışmanın amacı akut inmeli hastalarda serum S100B seviyeleri ile lezyonun tipi ve büyüklüğü arasındaki ilişkiyi tespit etmektir.

Akut serebrovasküler olay geçiren 62 hasta çalışmaya dahil edildi.26 sağlıklı kontrol grubu olarak belirlendi. Örnekler hastaların hastaneye başvurusundan 24 saat içerisinde alındı. Hastalar kranyal bilgisayarlı tomografi ve manyetik rezonans tetkikleri kullanılarak lezyonların tipine göre iskemik ve hemorajik inme gruplarına ayrıldılar. İskemik grup Bamford sınıflamasına göre total anterior sirkülasyon enfarktları (TACI), kısmi anterior sirkülasyon enfarktları (PACI) ve posterior sirkülasyon enfarktları (POCI) gruplarına olmak üzere 3 gruba ayrildilar.

Çalışmamızda iskemik ve hemorajik gruplar arasında S100B değerleri açısından istatistiksel olarak anlamlı fark saptanmadı. Ancak kontrol gruplarına kıyasla iskemik ve hemorajik gruplarda yerleşim yeri ve lezyon büyüklüğü açısından istatistiksel olarak anlamlı derecede fark saptand1.

Çalışmamızın sonuçları S100B seviyelerinin iskemik ve hemorajik inme sonrası beyin hasarının belirteci olarak kullanılabileceğini göstermiştir ancak mutlak bir karar için bu konuda daha çok çalışmanın yapılması gerekmektedir.
\end{abstract}

Anahtar Kelimeler: Akut serebrovasküler olay, serum S100B protein

\begin{abstract}
The aim of the study is to access whether there is a relationship between lesion type and size and serum protein s100B levels in patients with acute stroke.

62 patients with acute cerebrovascular accident were enrolled to the study. 26 healthy age matched people are used as controls. Serum samples of the patients were obtained within 24 hours after admission. All the patients were divided into ischemic and hemorrhagic groups according to the type of lesion confirmed by CT and/ or MRI. The group with ischemic lesions are analysed by dividing into 3 groups according to lesion localisation and size as total anterior circulation infarcts (TACI), partial anterior circulation infarcts (PACI) and posterior circulation infarcts (POCI) with Bamford classification.

In our study we found no statistically significant differences between levels of protein S100 B levels both in hemorrhagic and ischemic stroke groups. When analysed in terms of localisation and volume we found a statistically significant difference both in ischemic and hemorrhagic groups in terms of S100B levels when compared to normal controls.

The results of our study revealed that serum S100 B levels can be used as an indicator of brain injury after ischemic and hemorrhagic stroke but more studies are required about this relationship to make an accurate deduction.
\end{abstract}

Keywords: Acute serebrovascular Stroke, serum S100B protein
KÜ Tip Fak Derg 2014; 16(2): 8-14

Received / Geliş Tarihi: 17.03 .2014

Accepted / Kabul Tarihi: 20.04.2014
Yazışma Adresi / Correspondence: Murat ALPUA

Kırıkkale Üniversitesi Tıp Fakültesi, Nöroloji A.D., KIRIKKALE, E-mail: dr.muratalpua@yahoo.com 


\section{GíRiş}

İnme sadece gelişmiş ülkelerde değil, tüm dünyada da koroner kalp hastalığı ve tüm kanserlerin ardından üçüncü sıkl1kta gelen ölüm nedenidir. İnme insidensi güvenilir çalışmaların yapılabildiği beyaz popülasyonların çoğunda birbirine yakındır ve ortalama olarak bir y1lda, her 1000 kişide 2 yeni inmenin ortaya çıktığı hesaplanmıştır.

S100, omurgalılarda bulunan kalsiyum-modüle proteinlerden multijenik bir ailedir. S100B, S100 ailesinin bir üyesidir. S100B, 21 kDA moleküler ağırlığa sahip, 2 beta ünitesinden oluşan homodimer bir asidik proteindir. S100B'nin nöronal gelişim, farklılaşım ve beynin onarımında önemli bir faktör olduğu ve serebral hasardan sonraki ekstraselüler konsantrasyonundaki artışlardan kaynaklanan ek hücre hasarlarının da nörodejeneratif oluşum patofizyolojisinde rol aldığı öne sürülmektedir. S100B, serebral hasarda beyin omurilik sivisina (BOS) ve daha sonra kana rahatllkla geçmektedir (1-3).

S100B'nin insan kan ve beyin omurilik sivisında travmatik beyin hasarı sirasında arttı̆̆1 gösterilmiştir.S100B'nin çeşitli iskemik durumlardaki seviyeleride birçok çalışmada incelenmiş ve artmış bulunmuştur. $\mathrm{Bu}$ çalışmaların çoğu iskemik beyin hasarlarında kolay ölçülebilen ve erken prognostik değere sahip bir biyolojik belirleyici bulma amacındadır. $\mathrm{Bu}$ nedenden dolayı bu çalışmalarda S100B, klinik nörolojik bulgular ve/veya enfarkt volümü ile korelasyonu incelenmiştir (4).

Son yıllarda inmeli hastaların tanımlanmasında beyin hasarlarının biyokimyasal belirleyicileri önem kazanmıştır. Bizim bu çalışmamızdaki amacımız, inmeli hastalarda S100B düzeylerinin ölçülmesi ve lezyon tipi, enfarkt boyutu, lokalizasyonu ile ilişkisini araştırmaktır.

\section{GEREÇ VE YÖNTEM}

Çalışmada Sağlık Bakanlığı Numune Eğitim ve Araştırma Hastanesi Nöroloji Kliniğine Ağustos 2011Eylül 2011 tarihleri arasında başvuran, anamnez, fizik ve nörolojik muayeneleri ayrıntılı olarak yapılan, nöroradyolojik inceleme ile hemorajik (intraserebral kanamalar) ve iskemik serebrovasküler hastalık tanısı kesinleştirilen, yatışı yapılarak takip ve tedavisi yapılan 62 hasta $(30 \mathrm{~K}, 32 \mathrm{E})$ prospektif olarak değerlendirildi.

\section{Çalışma dışı bırakılan hastalar}

İnme nedeni travma, tümör, enfeksiyon gibi nedenlere bağlı infarkt veya kanama olanlar, geçirilmiş serebrovasküler olay (SVO), kafa travması öyküsü, mevcut üremi, siroz, malignensi, kronik kalp ve kronik akciğer hastalığı içeren sistemik hastalığ geçici iskemik atak (GİA) geçiren hastalar, epidural, subdural hematom tablosu ile başvuran hastalar, subaraknoid kanama (SAK) ile başvuran hastalardır.

Çalışmaya alınan olguların anamnezlerinde yaşları, cinsiyetleri, eşlik eden bulgular, biyokimyasal tetkikleri, ilk başvuru anında, 3.gün ve 7.gün yapılan nörolojik muayeneleri ve radyolojik görüntüleme Kranyal Bilgisayarlı Tomografi (BT) veya Manyetik Rezonans Görüntüleme (MRG) sonuçları dosyalarından kayıt edildi.

Hastalarımıza ilk nörolojik değerlendirmeyi yapmak için uygulanan NIH İnme skalası kullanıldı. Tüm hastaların klinik bulguları çekilen Kranyal BT veya MRG sonuçlarına göre iskemik inme subtipleri Bamford Klinik Klasifikasyonuna göre sınıflandırıldı (5).

Çalışmaya alınan tüm hastalardan inme başlangıcından itibaren 24 saat içinde serum S100B düzeyi ölçümü için, antekubitial venden biyokimya tüplerine $10 \mathrm{ml}$ kan örneği alındı. Örnekler 800-1000 RPM'de 10 dakika santrifüj edilerek serumları ayrıldı. 
Elde edilen serumlar her hasta için ayrı tüpe konulduktan sonra çalışma gününe kadar_muhafaza edildi. Lipemik örnekler kullanılmadı. Analizin yapılacağı gün dondurulmuş serum örneklerinin oda 1sısında çözünmesi sağlandı. Tekrarlanan dondurma ve çözme işleminden kaçınıldı. Analiz Sağlık Bakanlığı (S.B.) Ankara Numune Eğitim ve Araştırma Hastanesi Biyokimya Laboratuvarı'nda yapıldı.

\section{S100B Ölçümü}

Çalışmamızda serum S100B düzeyleri Biovendor firmasının üretimini yaptığı ELİSA S100B kiti ile ELİSA yöntemiyle ölçüldü. Human S100B ELİSA, S100B proteinini serum ve serebrospinal sıvıda invitro saptayabilmek için kullanılan immün belirteçtir.

\section{İstatistiksel Değerlendirmeler}

İstatistiksel analizler SPSS for Windows Version 15.0 paket programı ile yapıldı. Sayısal değişkenler ortalama \pm standart sapma, median ve minimummaksimum ile gösterilirken, kategorik değişkenler sayı ve yüzde ile ifade edildi. Kontrol ve hasta grup arasında cinsiyet bakımından farklılık olup olmadığı khi kare testi ile incelendi. İki grup arasında S100B bakımından farklılık olup olmadığına Mann Whitney U testi ile bakıldı. Hasta grup içinde S100B seviyesine risk faktörleri, cinsiyet, yaş ve SVO tipinin etkisi olup olmadığı Mann Whitney U testi ile incelendi. S100B seviyesi ile NIHSS ve Rankin skorları arasındaki ilişkiye Spearman korelasyon katsayısı ile bakıldı. Anlamlılık düzeyi $\mathrm{p}<0,05$ olarak belirlendi.

\section{BULGULAR}

Çalışma Ağustos- Eylül 2011 tarihleri arasında S.B. Ankara Numune Eğitim ve Araştırma Hastanesi Nöroloji Kliniğinde inme tanısıyla yatırılarak takip ve tedavi edilen, yaşları 45 ile 90 arasında değişen 32 (\% 52) erkek ve 30 kadın (\% 48) olmak üzere toplam 62 olgu üzerinde yapıldı. Olguların ortalama yaşı 71,6 \pm 9,8 idi. Kontrol grubu 26 sağlıklı gönüllüden oluşturuldu. Kontrollerin ortalama yaşı $68,8 \pm 11,2$ idi. Hasta grubunda ortalama S100B seviyesi 23,3 iken kontrol grubunda bu 11,8 idi. Hasta ve kontrol grupları S100B bakımından kıyaslandığında hasta grubu ortalama S100B seviyesi kontrol grubuna göre istatiksel olarak anlamlı derecede yüksek saptanmıştır $(\mathrm{p}<0,001)$. Grafik 1'de hasta ve kontrol grubunun S100B değerleri karşılaştırılmıştır.

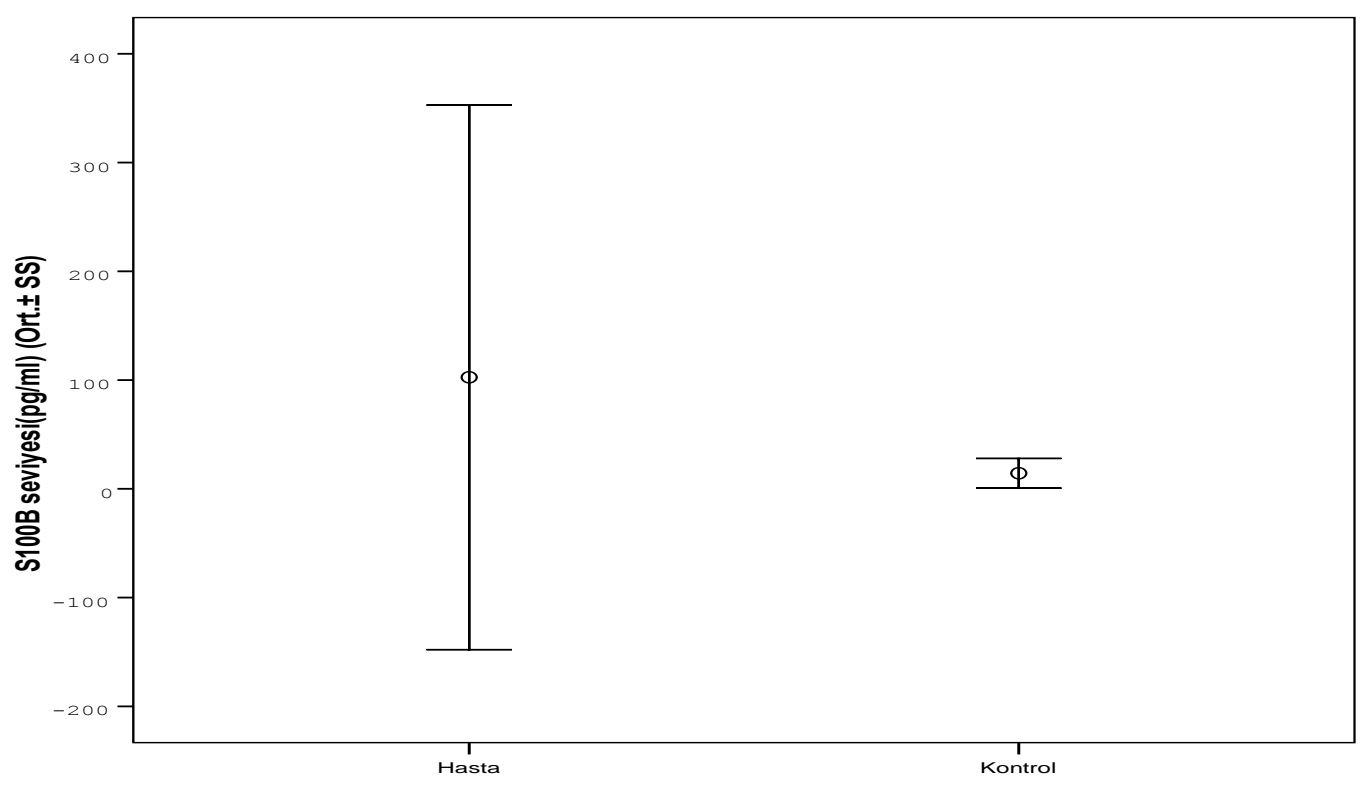

Grafik 1 - Hasta ve kontrol grubunda S100B değerlerinin karşılaştırılması 
Yaş ve Cinsiyet: Kadınlarda median S100B seviyesi 21,3, erkeklerde 23,3'tü. Yetmiş yaş üzerinde median S100B seviyesi 23,9 iken, yetmiş yaş altında 16,0 idi. Yaş ve cinsiyet dağılımına göre S100B seviyeleri açısından gruplar arasında istatistiksel olarak anlamlı bir farklılık saptanmadı $(\mathrm{p}>0.05)$.
S100B Değerleri: İskemik grupta ortalama S100B seviyesi 106,3 iken, hemorajik grupta 91,7 idi. Hemorajik ve iskemik inmeli olgularda S100B değerleri karşılaştırıldığında değerler arasında istatistiksel olarak (p>0.05)anlamlı farklılık saptanmadı. Grafik 2'de hemorajik ve iskemik grup S100B değerleri karşılaştırılmıştır.

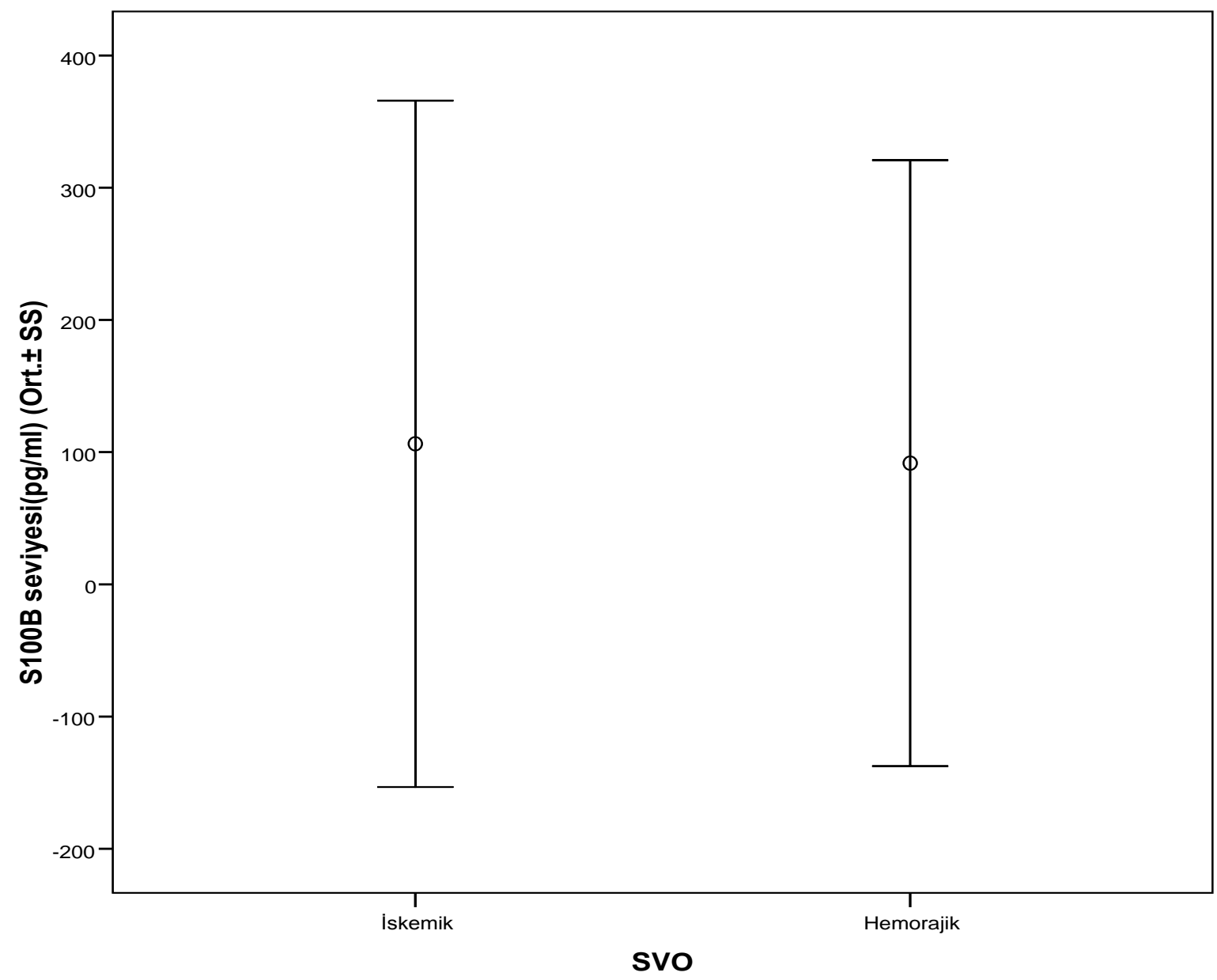

Grafik 2 - İskemik ve Hemorajik grupta S100B seviyeleri

İskemik İnme Subtiplerine göre S100B Seviyeleri: TACI grubunda ortalama S100B değeri 198,2 iken PACI grubunda 104,7 ve POCI grubunda 81,6 idi. İskemik inmeli olgular, TACI, PACI ve POCI olarak gruplandırılarak S100B değerleri karşılaştırıldığında değerler arasında istatistiksel olarak anlamlı farklılık saptand1 $(\mathrm{P}<0.05)$. TACI grubunun diğer iki gruba göre daha yüksek S100B değerlerine sahip olduğu istatiksel olarak saptand1. Grafik 3'te her üç grubun S100B değerlerinin karşılaştırılması verilmiştir. 


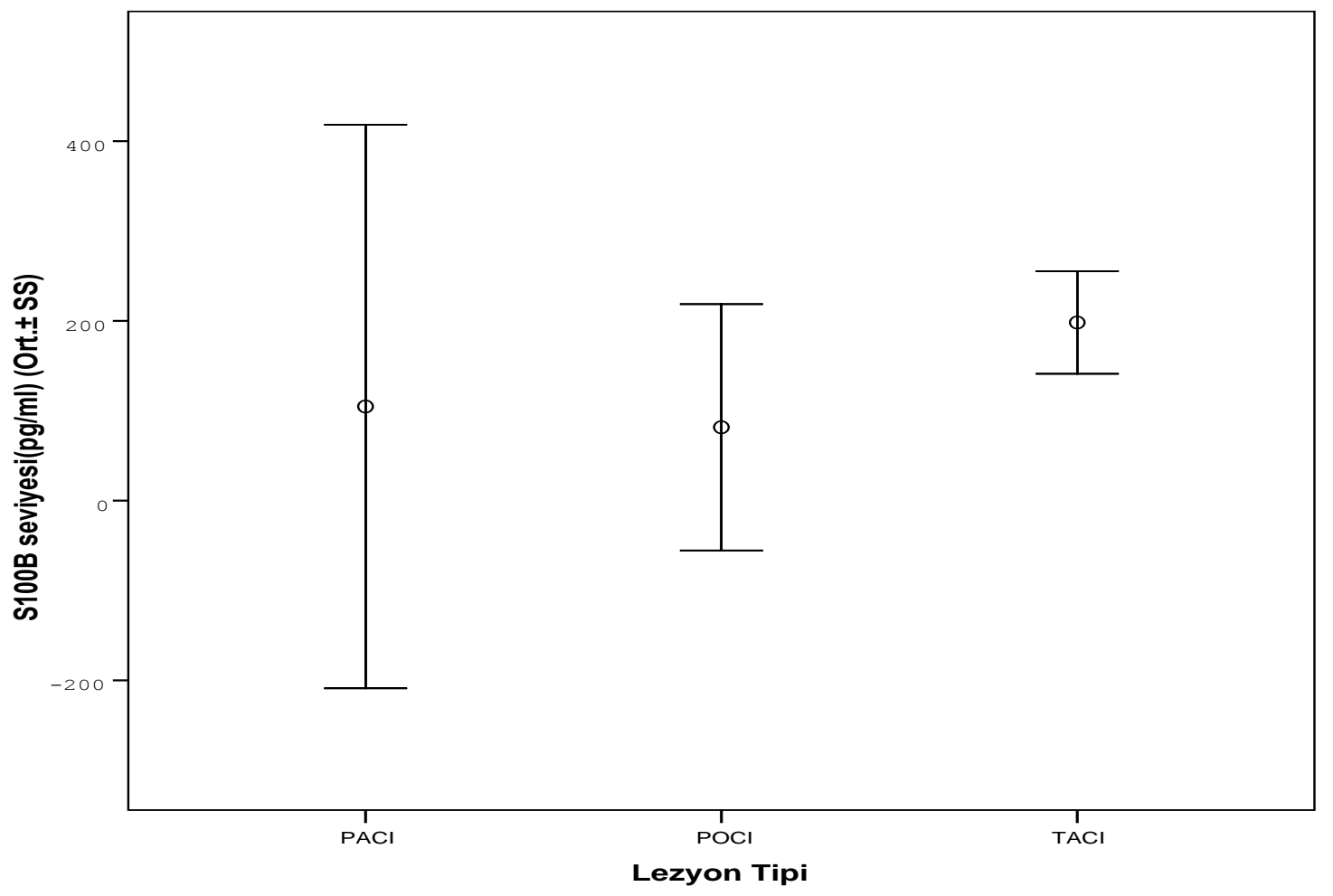

Grafik 3 - İskemik SVO tipleri arasında S100B karşılaştırılması

Lezyon Lokalizasyonları ile S100B ilişkisi: Lezyon lokalizasyonları arasında S100B bakımından farklılık saptanmıştır. $(p=0,006)$. İskemik inme grubunda MCA ve serebellar lokalizasyonlu grupta diğer gruplara göre daha yüksek S100B seviyeleri saptanmıştır.
Hemorajik inmeler içinde bazal ganglia grubunda S100B değerlerinde diğer gruplara kıyasla anlamlı derecede farklılık saptanmıştır. Lezyon lokalizasyonlarına göre S100B değerlerinin karşılaştırılması gösterilmiştir (Grafik 4).

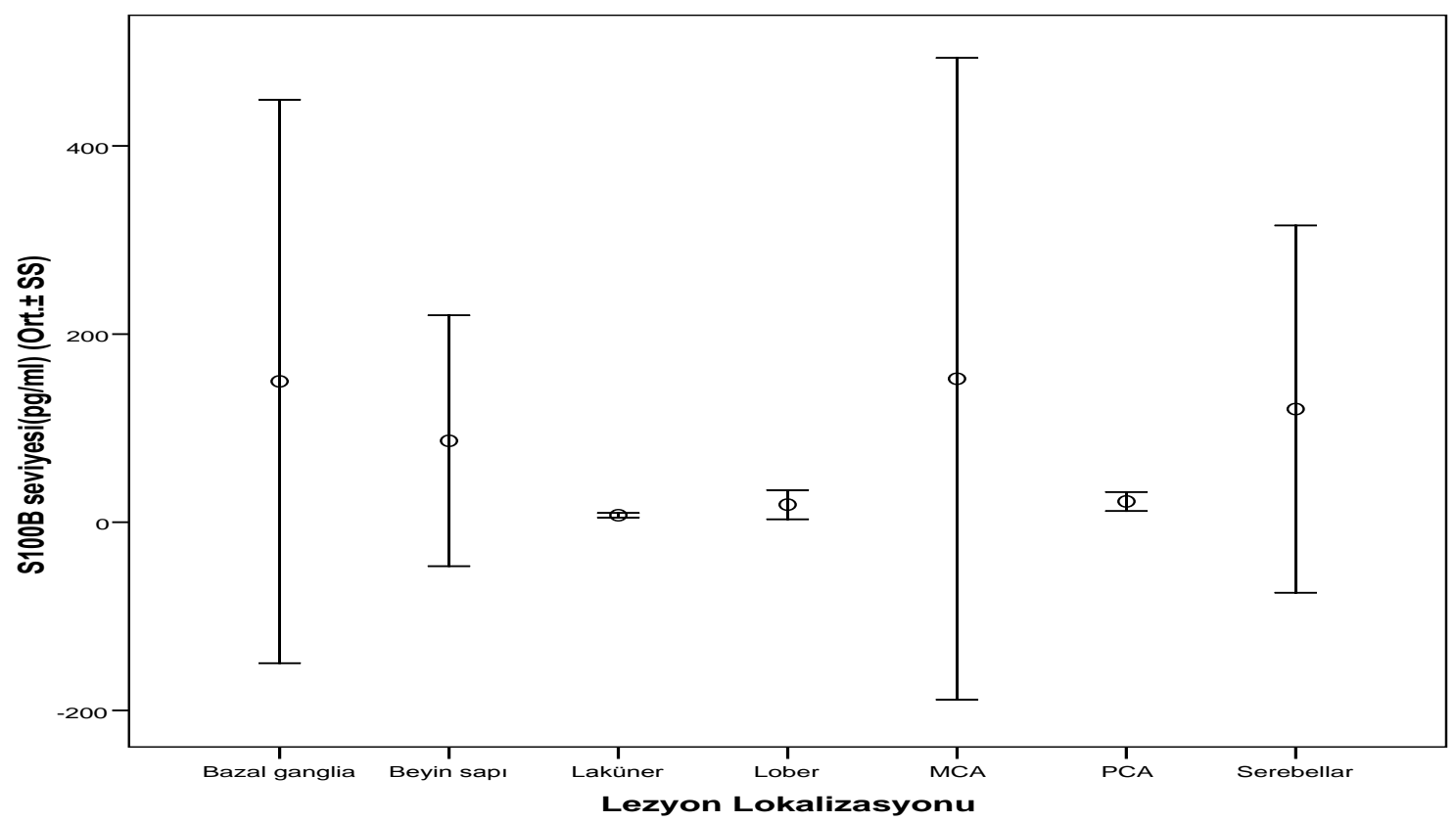

Grafik 4 - Lezyon lokalizasyonları arasında S100B değerlerinin karşılaştııılması 


\section{TARTIŞMA}

Son yıllarda çeşitli santral sinir sistemi hastalıklarında beyin hasarına bağlı nörobiyokimyasal belirteçlerin analizine ilgi gittikçe artmaktadır. Klinik çalışmalarda periferik kanda saptanabildiği için protein S100B ve Nöron Spesifik Enolaz en sık kullanılan biyokimyasal belirteçler olmuştur.

Protein S100B astrositlerde ve Schwann hücrelerinde bulunan kalsiyuma bağlı protein grubunun bir üyesidir. Proteinin biyolojik özellikleri tam aydınlatılmasa da S100B'nin komplike nöroglial etkileşimleri modüle ettiği ortadadır. Çeşitli deneylerde serebral hasardan sonra geçen zamana ve S100B konsantrasyonlarına bağlı olarak hem yıkıcı (nöronal hücre ölümü indüksiyonu), hem de faydalı (reaktif sinaptogenez ve plastisite oluşumunun indüksiyonu) etkisi gösterilmiştir. Protein S100B yalnızca beyin dokusunda bulunmamaktadır. Birçok dokuda hem fizyolojik hem de patolojik durumlarda bulunabilmektedir (6).

Protein S100B, beyaz ve kahverengi yağ dokusunda, deride, iskelet kas dokusunda, melanom ve glioblastom hücrelerinde ve $\beta$-adrenerjik agonistler ile veya fosfodiesteraz inhibitörleri ile uzun süre tedavi edilen hastalarda bulunmuştur. Ancak akut santral sinir sistemi hasarlarından sonra S100B aktivitesi diğer durumlarda bulunduğundan belirgin olarak daha yüksektir $(7,8)$.

Serebrovasküler olay sonrası beyin hasarında, travmatik beyin hasarında, kardiyopulmoner bypass eşliğindeki kardiak ameliyatlarda ya da kardiak arrestten sonra S100B proteinin artışı spesifik bulunmuştur (9).

S100B proteini dejenere olmuş astrositler tarafından salınır. Molekül bütünlüğünü kaybeden kan-beyin bariyerini aştıktan sonra periferik dolaşımda saptanabilir. Akut serebrovasküler olaydan sonra serumda veya periferik kanda protein S100B'nin salınımı ile ilgili birçok çalışma yapılmıştır ve bu proteinin lezyon volümü, klinik durum, fonksiyonel sonuç ile ilişkisi gösterilmiştir. SVO sonrası serum S100B protein konsantrasyonlarının beyindeki enfarkt alanı boyutuyla belirgin korelasyonu rapor edilmiş ve beyin kaynaklı proteinlerin salınım paterninin akut inme veya travmatik beyin hasarındaki patofizyolojiyi yansıtabileceği tahmin edilmiştir. Birçok klinik çalışmada, inme sonrası erken serum S100B konsantrasyonu ile klinik ve/veya fonksiyonel sonucun bağlantısı gösterilmiştir $(10,11)$.

Çalışmamızda akut serebrovasküler olaylı hastalar, lezyon tipine göre iskemik $(n=46)$ ve hemorajik $(n=16)$ olarak iki alt gruba ayrıld1. Literatürlerle uyumlu olarak iskemik ve hemorajik inmeli hastalarda sağlıklı kontrollere göre serum S100B düzeylerinde anlamlı fark saptand $1(\mathrm{p}<0.05)$. Ancak iskemik ve hemorajik inme grupları arasında S100B seviyesi açısından anlamlı fark saptanmadi $(p>0.05)$. İskemik ve hemorajik grup arasında fark saptanmaması eşit ya da birbirine yakın volümde serebral hücre hasarlanması olduğundan dolayı olabilir şeklinde açıklanabileceğini düşündük.

Çalışmamızda iskemik inmeli olgular, klinik bulgu ve kraniyal görüntülemedeki lezyon lokalizasyon ve büyüklüğüne göre total anterior sirkülasyon infarktları $(n=4)$, parsiyel anterior sirkülasyon infarktları $(n=29)$, posterior sirkülasyon infarktları $(n=13)$ olarak ayrıldı. Gruplararası S100B değerleri karşılaştırıldığında değerler arasında diğer iki gruba kıyasla TACI grubunda istatistiksel olarak anlamlı farklılık saptand 1 $(\mathrm{p}<0.05)$. İskemik inmeli olgular ile hemorajik SVO'lu olgular S100B düzeyleri açısından karşlaştırıldı ancak gruplar arası anlamlı fark saptanmadı. İskemik inme grubunda orta serebral arter ve serebellar lokalizasyonlu grupta, hemorajik inme grubunda ise bazal ganglia grubunda S100B değerlerinde diğer gruplara kıyasla anlamlı derecede farklılık saptanmıştır.

Hasta ve kontrol grubu arasinda S100B seviyesi bakımından istatiksel olarak anlamlı farklılık saptanmıştır $(p<0,001)$.Yaş ve cinsiyet dağılımına göre 
gruplar arasında S100B seviyeleri açısından istatistiksel olarak anlamlı bir farklılık saptanmadı ( $p>0.05$ ).Hemorajik ve iskemik inmeli olgularda S100B değerleri karşılaştırıldığında değerler arasında istatistiksel olarak (p>0.05) anlamlı farklılık saptanmad1. İskemik inmeli olgular, TACI, PACI ve POCI olarak gruplandırılarak S100B değerleri karşılaştırıldığında değerler arasında istatistiksel olarak anlamlı farklılık saptand 1 ( $<<0.05)$.TACI grubunun diğer iki gruba göre daha yüksek S100B değerlerine sahip olduğu istatiksel olarak saptandı. Lezyon lokalizasyonları arasında S100B bakımından farklılık saptanmıştır. $(p=0,006)$. ̇̇skemik inme grubunda MCA ve serebellar lokalizasyonlu grupta, hemorajik inme grubunda ise bazal ganlia grubunda S100B değerlerinde diğer gruplara kıyasla anlamlı derecede farklılık saptanmıştır.

Sonuç olarak, iskemik ve hemorajik inme, protein S100B'nin kana salınmasına sebep olmaktadır ve salınım kinetiği farklıdır. S100B salınım paterni ile vasküler lezyonun büyüklüğü arasında iyi bir korelasyon vardır. S100B proteini, inme sirasındaki beyin hasarının belirtecidir. BT'de görüntülenen gerçek beyin hasarının periferik kanda gösterilebilmesini sağlayan parametre olarak kullanılabilir.

\section{KAYNAKLAR}

1. Rosaria D. Intracellular and Extracellular Roles of s100 proteins Microscopy Research and Technique. 2003; 60: 540-51

2. Rothermundt M, Peters M, Preehn JH, Arolt O. $\mathrm{S} 100 \mathrm{~B}$ in Brain Domage and neurodegenaration. Microsc Res Tech. 2003; 60 (6): 614-32

3. Heinzmann WC, Fritt G, Schoter WB. S100 Proteins: Structure, Functions and Pathology. Frontiers in Bioscience Zurich. 2002; 7: 1356: 1368.
4. Wolf PA, D'Agustino R. Secular trends in stroke in the Framingham Study. Ann Epidemiol. 1993; 3: 471-75.

5. MacMahon S, Rodgers A. The epidemiological association between blood pressure and stroke: implications for primary and secondary prevention. Hypertens Res. 1994; 17(suppl 1): 23-32.

6. Shafer BW, Heinzmann CW. The S100 Family of EF-hand calcium-binding proteins, functions and pathology. Trends Biochen Sci. 1996; 21: 134-40.

7. Ig EC, Shafer BW, Heizmann CW. Expression pattern of S100 calcium-binding protein in human tumors. Int J Cancer. 1996; 68: 325-32.

8. Kahn HJ. Baurnal R, Van Eldik LJ, Dunn RJ, Marks A. Immunoreactivity of S100B in heart, skeletal muscle and kidney in chronic lung disease: possible induction by cAMP. Mod Pathol. 1991; 4: 698-701.

9. Hermann M, Vos P, Wunderlich MT, de Bruijn DHMM, Lamers KJB. Release of glial tissuespecific proteins after acute stroke. A comparative analysis of serum concentrations of protein S100B and glial fibrillary acidic protein. Stroke 2000; 31 : 2670-77.

10. Bertsch T, Cassarin W, Kretechmar M, Zimmer W, Walter S, Sommer C, Muehlhuser F, Ragoschke A, Kuehl S, Schmidt R, Pohlmann-Eden B, Nassabi C, Nichterlein T, Faßbender K. Protein S100B:a serum marker for ischemic and infectious injury of cerebral tissue. Clin Chem Lab Med. 2001; 39: 31923.

11. Hermann M, Vos P, Wunderlich MT, de Bruijn DHMM, Lamers KJB. Release of glial tissuespecific proteins after acute stroke. A comparative analysis of serum concentrations of protein S100B and glial fibrillary acidic protein. Stroke. 2000; 31. 